DOI: $10.31866 / 2616-7468.2 .2 .2019 .188209$

\section{ІННОВАЦІЙНІ ТЕХНОЛОГІї СОУСУ
МАЙОНЕЗ}

Ігор Грищенко,

кандидат технічних наук,

доцент, професор,

Київський національний університет

культури і мистецтв,

Київ, Україна,

grinnicol022@gmail.com

https://orcid.org/0000-0001-9134-8456

(C) Грищенко I., 2019

\section{Надія Кравчук,}

кандидат технічних наук, доцент,

Національний університет

харчових технологій,

Київ, Україна,

kr.nadiya@gmail.com

https://orcid.org/0000-0002-5405-6275

(c) Кравчук Н., 2019

\section{Олена Зборовська,}

асистент,

Київський національний університет

культури і мистецтв,

Київ, Україна,

alena-vlad2013@meta.ua

https://orcid.org/0000-0002-7297-8695

(C) Зборовська O., 2019

Актуальність. Розглянуто доцільність використання купажів рослинних олій для корекції недостатності ПНЖК та рослинної сировини у технології виробництва соусів майонезів. Використання купажованої олії, збалансованої за жирнокислотним складом та морквяного порошку, поєднання запропонованих співвідношень усіх компонентів забезпечує оригінальні органолептичні показники майонезу та водночас надає йому функціональних властивостей, підвищує харчову та біологічну цінність. Мета і методи. Meта cmammi обгрунтувати та розробити технологію соусу майонезу, збагаченого бета-каротином. $M e-$ тоди дослідження - органолептичні, фізико-хімічні, структурно-механічні, статистичні. Результати. Розроблено технологію соусу майонезу на основі купажу кукурудзяно-оливкової олії та морквяного порошку зі збалансованим жирнокислотним складом. Висновки та обговорення. Встановлено, що використання рослинних компонентів, а саме морквяного порошку та купажованих олій у технології майонезів дозволяє отримати харчовий продукт підвищеної харчової цінності. Це дозволить розширити асортимент соусів, збагатити їх жиророзчинними вітамінами, антиоксидантами та ПНЖК класу $\omega-6$ та $\omega-3$ в оптимальному співвідношенні.

Ключові слова: майонез, олія, порошок із моркви, соус, поліненасичені жирні кислоти (ПНЖК).

\title{
Актуальність проблеми
}

Перехід до ринкових відносин, розширення споживчих ринків, впровадження нових форм господарювання відобразились у всіх сферах економічного життя, 
в тому числі у сфері ресторанного бізнесу. На сьогоднішній день у ресторанному господарстві успішно функціонують лише ті заклади, які спромоглися вдовольнити бажання споживачів найкращим чином і при цьому невпинно удосконалюють свій ресторанний продукт для підтримання його належного рівня відповідно до постійно зростаючих вимог споживачів. Для покращення попиту підприємства ресторанного господарства використовують новітні технології виробництва продукції.

Відомо, що серед продукції ресторанного господарства окремий сегмент становлять соуси, які сприяють кращому засвоєнню харчових нутрієнтів організмом людини, урізноманітнюють асортимент і підвищують харчову цінність страв. Близько 70 \% страв, що подають у закладах ресторанного господарства, відпускають із соусом, що дозволяє не тільки покращити аромат, зовнішній вигляд та смак готової страви, але й підвищити вміст ессенціальних речовин. Проте більшість із них має незбалансований хімічний склад, зокрема, підвищений вміст насичених жирних кислот, а вуглеводний склад представлено переважно крохмалем пшеничного борошна (Пересічний \& Кравченко, 2002).

Перспективним напрямом вирішення завдання щодо підвищення харчової цінності, зниження дефіциту есенційних речовин є розроблення технології соусів функціонального призначення, що передбачає поєднання традиційної сировини з дієтичними добавками. Це дозволить отримати якісну і безпечну продукцію, збагачену фізіологічно важливими для організму людини нутрієнтами.

Для підвищення харчової цінності і зниження калорійності часто використовують основу для соусів із рослинних продуктів. Інтерес до розробки нових функціональних продуктів неухильно зростає через комплексні дослідження, які підтверджують безпосередній вплив деяких компонентів харчування, таких як поліненасичені жирні кислоти, антиоксиданти, вітаміни, мінерали, харчові волокна, на здоров'я людини (Нечаев, 2007).

Емульсійні олієжирові продукти (майонези, соуси майонезні), найважливішим компонентом яких є жировміщуючі нутрієнти, в харчуванні населення України та інших країн стали активно використовувати нещодавно, але вони вже привернули до себе увагу як продукти, що здатні надавати високих смакових властивостей їжі (Ипатова, Кочеткова, \& Нечаев, 2006).

Майонез є універсальним соусом, який поєднується за смаком із найрізноманітнішими стравами - холодними і гарячими, м’ясними і рибними, овочевими тощо. Водночас популярним є використання майонезу в суміші з іншими соусними основами або додавання його як смакової добавки в інші соуси. Майонези використовують як приправу для поліпшення смаку і засвоюваності продуктів, як добавку для приготування овочевих, рибних і м’ясних страв, у домашній кулінарії і підприємствах ресторанного господарства, а також для приготування бутербродів і десертів.

Актуальним завданням є розроблення купажів рослинних олій зі збалансованим жирнокислотним складом та впровадження їх у технологію соусів майонезів. Це дозволить розширити їх асортимент, збагатити жиророзчинними вітамінами, антиоксидантами та поліненасиченими жирними кислотами (ПНЖК) класу $\omega-6$ та $\omega-3$ в оптимальному співвідношенні. Найважливішими чинниками біологічної цінності таких продуктів є кількість і співвідношення ПНЖК. Аналіз існуючих підходів до збагачення харчових продуктів нетрадиційною сировиною показав, що $з$ цією метою використовують рослинні олії, які містять жиророзчинні вітамі- 
ни, антиоксиданти, але недоліком яких є незбалансоване співвідношення ПНЖК (Галицька \& Хижняк, 2014; Ипатова, Кочеткова, \& Нечаев, 2006).

Одним із основних пріоритетних напрямків у розвитку ринку даних продуктів було і залишається формування якості продукції, яка в подальшому визначає iï конкурентоспроможність. Якість продукту зумовлює не лише смак, запах, консистенція, але і його харчова цінність. Підвищення харчової цінності для емульсійних жирових продуктів може бути здійснено за рахунок методології комбінаторики складових рецептури, наприклад, олій, зокрема заміни соняшникової олії, яку головним чином використовують в Україні при виробництві цих продуктів, на кукурудзяно-оливкову, що особливо багаті на незамінні амінокислоти $\mathrm{w}-3$ та w-6. Переваги використання купажів рослинних олій для корекції недостатності ПНЖК перед біологічно активними добавками і лікарськими препаратами полягають у тому, що рослинні олії є традиційними харчовими продуктами, не дають ускладнень і побічних реакцій в організмі, а також значно дешевші за біологічно активні добавки, що важливо для малозабезпечених верств населення.

\section{Мета і методи дослідження}

Метою є обгрунтування та розробка технології виробництва соусу майонезу, збагаченого бета-каротином, зі збалансованим вмістом поліненасичених жирних кислот w-3 та w-6 груп.

Об’єктом дослідження у роботі були використані: порошок із моркви за ДСТУ 8654:2016; модельна система емульсії, яка приготовлена за традиційною технологією; модельні системи емульсій, які приготовлено з використанням порошку з моркви; майонез основний як контрольний зразок; майонез з кукурудзяно-оливкової олії з додаванням морквяного порошку як дослідний зразок.

Методи дослідження - органолептичні, фізико-хімічні, структурно-механічні, статистичні. Методологічною основою дослідження є харчова і біологічна цінність та показники органолептичного рівня і безпечності кулінарної продукції.

Інформаційна база дослідження - монографії, наукові статті, матеріали науково-практичних конференцій, нормативно-технічна документація.

\section{Результати дослідження}

Проведені аналітичні дослідження підтверджують необхідність розробки нових видів продукції високої біологічної цінності, яку можна отримати в результаті поєднання нетрадиційної сировини та створити на їх основі соус із новими властивостями.

Кукурудзяна олія рекомендована хворим на цукровий діабет, оскільки значно знижує рівень цукру у крові. Допомагає хворим на ожиріння, бо покращує обмін речовин та виводить шкідливі токсини з організму. $Є$ профілактикою ракових захворювань. Бореться з карієсом та лікує запалення ясен. Також фосфатиди (лецитин) кукурудзяної олії входять до складу клітинних мембран і відіграють важливу роль у забезпеченні функцій тканини головного мозку (Сімахіна \& Українець, 2010).

Оливкова олія знижує рівень поганого холестерину в крові, її помірне вживання служить профілактикою цукрового діабету, ожиріння, серцево-судинних захворювань. Вітамін Е, що входить до її складу, є високоактивним антиоксидантом, що допомагає організму в боротьбі зі старінням шкіри, покращує ріст волосся і стан нігтів, є профілактикою розвитку онкологічних захворювань. Вітаміни 
A, K, D у комплексі з вітаміном Е сприяють зміцненню тканин, м’язів кишечника, кісткової системи. Феноли, які присутні у складі олії, зміцнюють імунітет і уповільнюють процес старіння. Лінолева кислота вельми позитивно впливає на зір, сприяє поліпшенню координації рухів, регенерації тканин, швидкому загоєнню ран, опіків (Галицька \& Хижняк, 2014).

Для зниження енергетичної цінності та підвищення біологічної повноцінності соусу доцільним є використання порошку з моркви (ДСТУ 8654:2016), який $€$ джерелом харчових волокон, пектинових речовин та органічних кислот. У морквяному порошку у сконцентрованому вигляді збережено максимальну кількість каротиноїдів, вітамінів С та Е, які виступають у ролі антиоксидантів. Морквяний порошок дуже корисний для організму завдяки солідним запасам калію, фосфору, кальцію і натрію. За рахунок подібного поєднання зміцнює як травну і кровоносну системи, так і кістки, зуби, волосся. У ньому присутні також інші важливі елементи (залізо, магній, хлор, сірка) (Сімахіна \& Українець, 2010; Снєжкін \& Петрова, 2010).

Дослідження функціональних властивостей морквяного порошку важливо для розробки рецептур, вибору технологічних режимів приготування соусу. До найбільш важливих функціональних властивостей відносять вологозв'язуючу, емульгуючу, жироутримуючу здатність (Доценко, 2016). Визначали вологозв'язуючу (В33), емульгуючу (Е3) та жироутримуючу (ЖУЗ) здатність порошку з моркви залежно від доданої кількості в соус.

Результати досліджень функціональних властивостей: В33, Е3, ЖУЗ порошків із моркви наведено на рис. 1, 2, 3 відповідно.

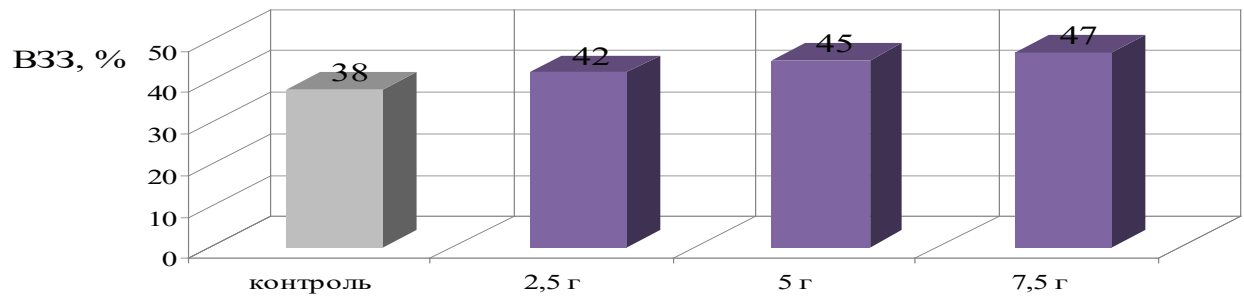

Кількість порошку 3 моркви

Puc.1. Вологозв'язуюча здатність (В33, \%) порошку з моркви

Fig. 1. Moisture-binding capacity (OZ,\%) of carrot powder

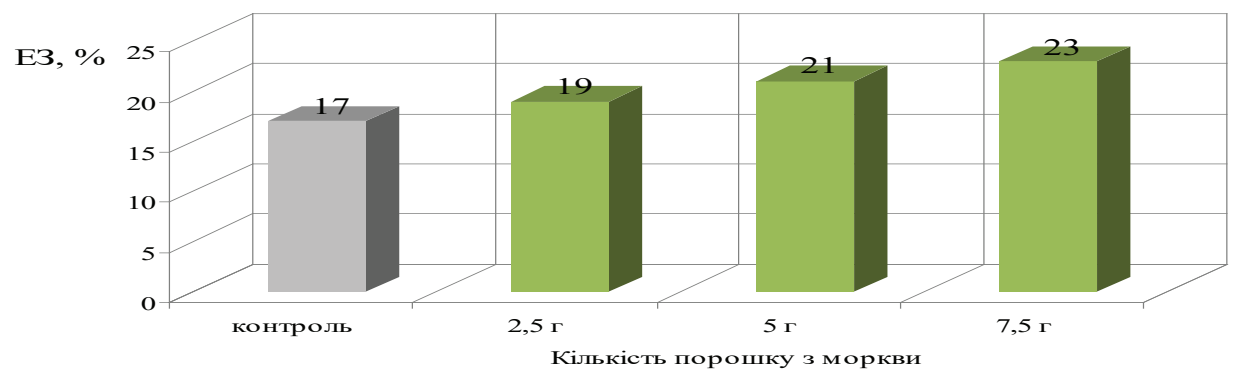

Puc. 2. Емульгуюча здатність (Е3, \%) порошку з моркви

Fig. 2. Emulsifying ability (EC,\%) of carrot powder 


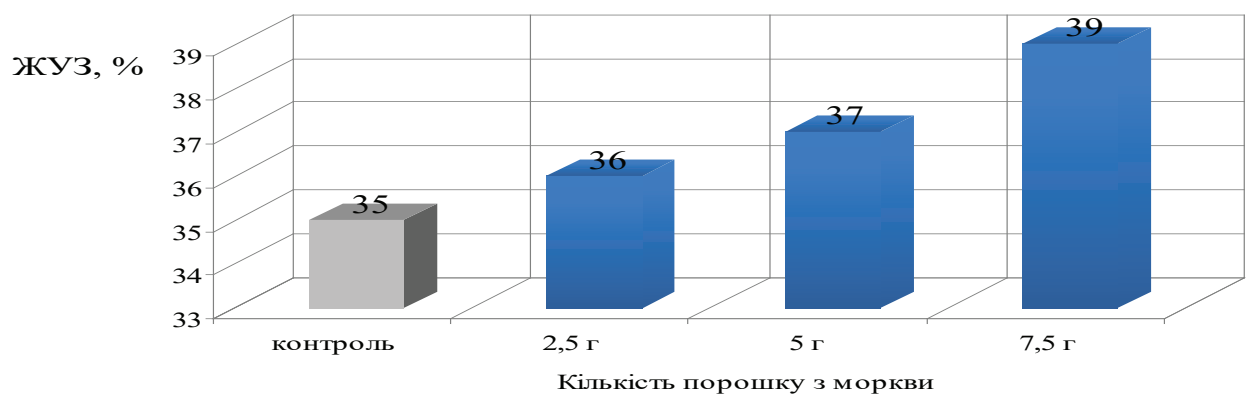

Puc. 3. Жироутримуюча здатність (ЖУЗ, \%) порошку з моркви

Fig. 3. The fat-holding capacity (ZHOZ,\%) of carrot powder

Вологозв'язуюча (В33) здатність є важливою характеристикою морквяного порошку, яка впливає на утворення соусу потрібної консистенції. Процеси утримання вологи різних видів зразків із різною кількістю порошку виявляють особливі здатності до вологоутримання, які збільшуються від кількості порошку у зразках. Це вказує про необхідність регулювання вологи для забезпечення в готових виробах необхідних структурно-механічних властивостей.

Поведінка морквяного порошку в даних емульсіях характеризує їх емульгуючу здатність (Е3). Підвищення стійкості емульсій відбувається завдяки зростанню в’язкості дисперсійного середовища.

Жироутримуюча здатність (ЖУЗ) характеризує здатність абсорбувати і утримувати жир (Осейко, 2006). Висока жироутримуюча здатність морквяного порошку впливає на утворення ніжної і однорідної текстури соусу, виключає відділення жиру (Снєжкін \& Петрова, 2010).

Дослідження технологічних властивостей - вологозв'язуючої, емульгуючої та жирозв’язуючої здатностей порошку з моркви - показало, що, окрім позитивного фізіологічного впливу, порошок забезпечить підвищену вологозв'язуючу (B33), емульгуючу (Е3) та жирозв’язуючу (Ж33) здатності порівняно з контрольним зразком.

Для дослідження фізико-хімічних показників соусів майонезів визначали вологість (вміст сухих речовин) - методом висушування та масову частку жиру - за ДСТУ 4560:2006 «Майонези. Правила приймання та методи випробування».

Дані досліджень зображені у вигляді діаграм (рис. 4 та рис. 5).

Дослідження кислотності, густини та стійкості емульсії наведено у табл. 1.

Табл. 1. Фізико-хімічні показники якості дослідних зразків майонезу

Table 1. Physio-chemical parameters of the quality of prototypes of mayonnaise

\begin{tabular}{|c|c|c|c|c|c|}
\hline \multirow[t]{2}{*}{ Показник } & \multirow[t]{2}{*}{$\begin{array}{c}\text { Вимоги ДСТУ } \\
\text { 4487:2005 }\end{array}$} & \multirow[t]{2}{*}{$\begin{array}{l}\text { Майонез- } \\
\text { контроль }\end{array}$} & \multicolumn{3}{|c|}{$\begin{array}{c}\text { Майонез із кукурудзяно- } \\
\text { оливкової олії з різним вмістом } \\
\text { морквяного порошку, г }\end{array}$} \\
\hline & & & 2,5 & 5,0 & 7,5 \\
\hline Кислотність, Т & Немає норми & 0,612 & 0,615 & 0,624 & 0,635 \\
\hline 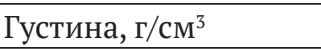 & Відповідно до ТО & 0,90 & 0,91 & 0,93 & 0,95 \\
\hline Стійкість емульсії, \% & Не менше 97 \% & 98 & 97 & 99 & 98 \\
\hline
\end{tabular}




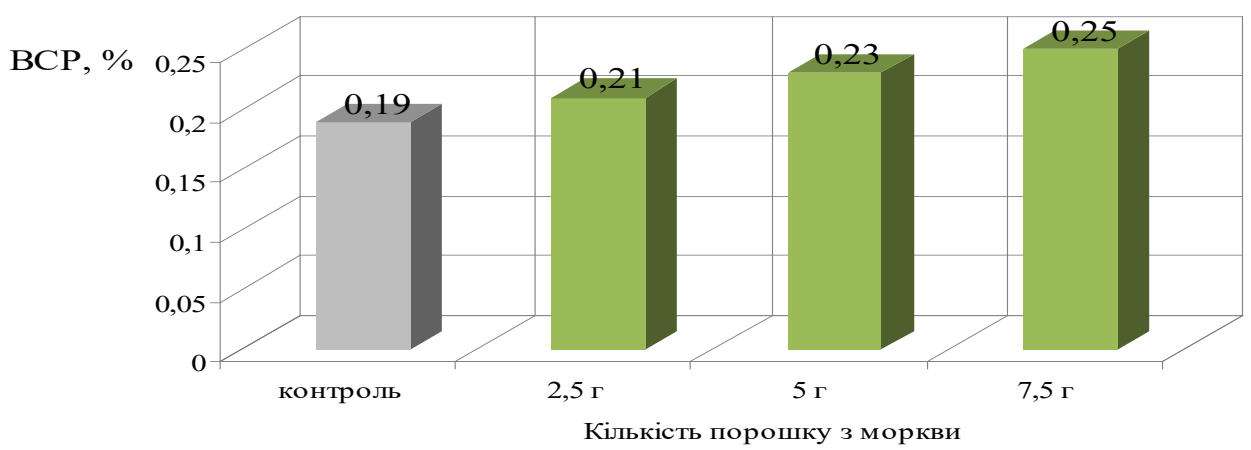

Puc. 4. Вміст сухих речовин у модельних зразках соусів

Fig. 4. Solids content in model samples of sauces

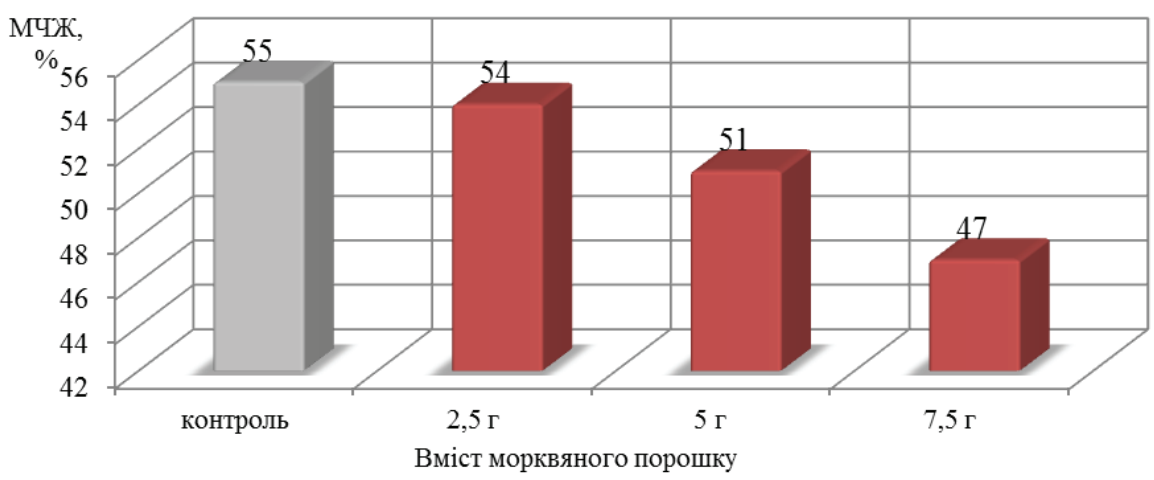

Puс. 5. Масова частка жиру в модельних зразках соусів

Fig. 5. Fat content in model samples of sauces

Математична обробка експериментальних даних, оцінка похибки експериментальних даних і вимірюваних величин здійснювалась за загальноприйнятими методиками.

Аналізуючи дані за фізико-хімічними показниками якості видно, що дослідні та контрольний зразки незалежно від вмісту порошку моркви відповідають вимогам нормативної документації. Значення кислотності, густини та стійкості емульсії наближені до значень із контрольним зразком (“Майонези”, 2005).

Можна дійти до висновку, що раціональною масовою часткою порошку 3 моркви $€ 5$ г, яка сприяє формуванню відповідної якості майонезу. Пропонується готувати майонез із введенням у рецептуру купажованої кукурудзяно-оливкової олії (59,5-55,8 \%) та морквяного порошку (3,5-4,5 \%), що дозволяє отримати продукт, збагачений харчовими волокнами, біологічно активними речовинами, зокрема бета-каротином та покращеним жирнокислотним складом. У табл. 2 приведений хімічний склад майонезу з купажу кукурудзяно-оливкової олії з додаванням морквяного порошку покращеної рецептури. Наявність у цьому продукті рослинних олій забезпечує біологічну цінність за рахунок поліненасичених жирних кислот, а енергетичну - за рахунок жирних кислот. 
Табл. 2. Хімічний склад майонезу з купажу кукурудзяно-оливкової олії із додаванням морквяного порошку

Table 2. Chemical composition of mayonnaise for blending corn and olive oil with the addition of carrot powder

\begin{tabular}{|l|c|}
\hline \multicolumn{1}{|c|}{ Компоненти } & Кількість \\
\hline Білки, \% & 2,8 \\
\hline Жир, \% & 67,0 \\
\hline Ненасичені жирні кислоти, \% & $5,8 \ldots 13$ \\
\hline Поліненасичені жирні кислоти, \% & $36,9 . .60$ \\
\hline Холестерин, мг \% & 0,1 \\
\hline Моно- і дисахариди, \% & 3,7 \\
\hline Вітамін В, мг \% & 14,3 \\
\hline Вітамін Е, мкг \% & 30,0 \\
\hline Вітамін В, мкг \% & 0,1 \\
\hline Вітамін В, мкг \% & 0,5 \\
\hline Вітамін В, мг \% & 0,01 \\
\hline Вітамін РР, мг \% & 0,1 \\
\hline Бета-каротин, мкг \% & 0,7 \\
\hline Ретиноловий еквівалент, мкг \% & 20,0 \\
\hline Ніациновий еквівалент, мг \% & 0,5 \\
\hline Фосфор (Р), мг \% & 54,0 \\
\hline Калій (К), мг \% & 38,0 \\
\hline Натрій (Ма), мг \% & 508,0 \\
\hline Магній (Мg), мг \% & 13,0 \\
\hline Кальцій (Са), мг \% & 33,0 \\
\hline Залізо (Ее), мг \% & 1,0 \\
\hline
\end{tabular}

Проведено дослідження органолептичних показників якості майонезу та балова оцінка споживчих властивостей. При визначенні органолептичної оцінки було проведено аналіз майонезів: контрольний зразок - майонез традиційної рецептури та майонез із підвищеною біологічною цінністю під назвою «Скіф». Органолептичні показники якості соусу були переведені за допомогою шкали Харінгтона у відносні одиниці і представлені у вигляді профілограм (рис. 6, 7).

Аналіз профілограм показав, що вищий бал має зразок майонезу «Скіф» порівняно з контрольним зразком (розраховано за методом «багатокутник якості») (Корецька \& Зінченко, 2003).

Це свідчить про придатність його до впровадження у виробництво і реалізації в умовах закладів ресторанного господарства.

Майонез у кількості кукурудзяно-оливкової олії 59,5-55,8 \% та морквяного порошку 3,5-4,5 \% має найкращі органолептичні показники, порівняно з іншими зразками. При цьому має однорідну консистенцію середньої густини. Приємний, добре виражений, характерний смак. 


\section{Балова оцінка споживчих властивостей}

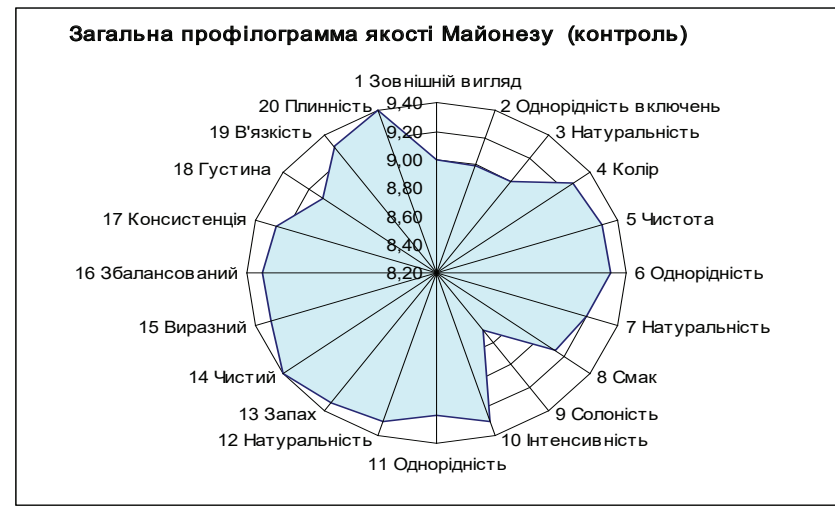

Puc. 6. Профілограма якості контрольного зразка майонезу Fig. 6. Profile of the quality of the mayonnaise control sample

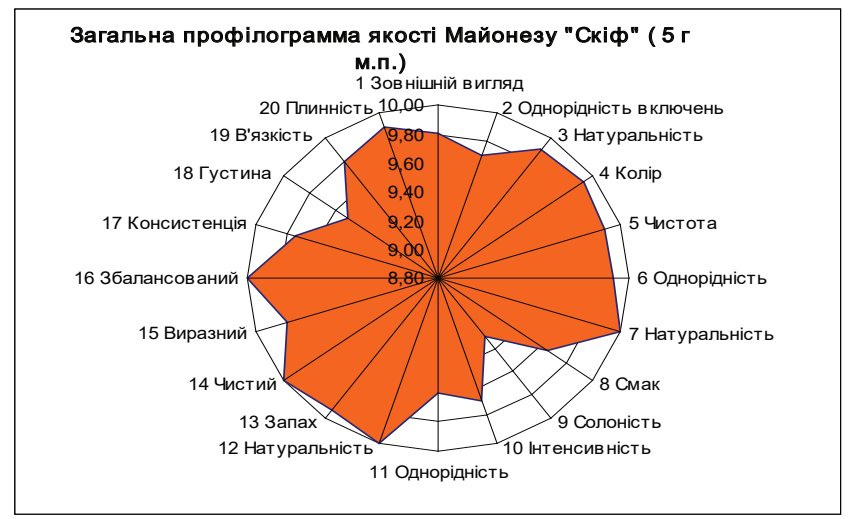

Puc. 7. Профілограма якості дослідного зразка майонезу «Скіф»

Fig. 7. Quality profile of the Scythe mayonnaise test sample

Табл. 3. Органолептична оцінка майонезі

Table 3. Organoleptic evaluation of mayonnaise

\begin{tabular}{|l|l|l|}
\hline \multirow{2}{*}{$\begin{array}{c}\text { Назва } \\
\text { покника }\end{array}$} & $\begin{array}{c}\text { Майонез традиційної } \\
\text { рецептури (ДСту4487:2005) } \\
\text { «айонези. Загальні технічні } \\
\text { умови» }\end{array}$ & $\begin{array}{c}\text { Майонез «Скіф» кукурудзяно- } \\
\text { оливковий із морквяним } \\
\text { порошком (5 г) }\end{array}$ \\
\hline $\begin{array}{l}\text { Зовнішній вигляд } \\
\text { та консистенція }\end{array}$ & $\begin{array}{c}\text { Однорідна кремоподібна суміш } \\
\text { Смак та запах }\end{array}$ & $\begin{array}{l}\text { Однорідна сметаноподібна } \\
\text { суміш із порошком моркви, що } \\
\text { рівномірно розподілена по масі }\end{array}$ \\
\hline Смак нечітко виражений, злегка & $\begin{array}{l}\text { Запах приємний із легким } \\
\text { гороматом моркви, легкий } \\
\text { післясмак }\end{array}$ \\
\hline Колір & Блідо-жовтитий & Жовто-оливковий \\
\hline
\end{tabular}




\section{Висновки та обговорення}

Використання купажованої олії, збалансованої за жирнокислотним складом, та морквяного порошку, поєднання запропонованих співвідношень усіх компонентів забезпечують оригінальні органолептичні показники майонезу та водночас надають йому функціональних властивостей, підвищують харчову та біологічну цінність. Отриманий соус за показниками якості відповідає встановленим вимогам.

\section{СПИСОК ПОСИЛАНЬ}

Галицька, Л.Ю., \& Хижняк, О.О. (2014). Нетрадиційна олієвмісна сировина в Україні. В Технічні науки: стан, досягнення і перспективи розвитку м'ясної, олієжирової та молочної галузей (с. 144-146), Матеріали 3 Міжнародної науково-технічної конференції. Київ: НУХТ.

Доценко, В.Ф. (Ред.). (2016). Лабораторний практикум із загальних технологій харчової промисловості. Київ: Кондор.

Ипатова, Л.Г., Кочеткова, А.А., \& Нечаев, А.П. (2006). Новые направления жировых продуктов. Масложировая промышленность, 4, 12-14.

Корецька, І.Л., \& Зінченко, Т.В. (2003). Оцінювання нових харчових виробів за допомогою критерію «Багатокутник якості». Наукові праці НУХТ, 14, 64-65.

Майонези. Загальні технічні умови. (2005). ДСТУ 4487:2005, 2005, 25 листопада. Київ: Український науково-дослідний інститут олій та жирів (УкрНДІОЖ) і асоціація "Укроліяпром".

Майонези. Правила приймання та методи випробування. (2006). ДСТУ 4560:2006, 2008, 1 січня. Київ: Український науково-дослідний інститут олій та жирів (УкрНДІОЖ) і асоціація "Укроліяпром".

Морква столова сушена. Технічні умови (2016). ДСТУ 8654:2016, 2017, 1 липня. Київ: ДП "УкрНДНЦ".

Нечаев, А.П. (2007). Научные основы технологий получения функциональных жировых продуктов нового поколения. Масла и жиры, 8, 26-27.

Осейко, M.I. (2006). Технологія рослинних олій. Київ: Варта.

Пересічний, М.I., \& Кравченко, М.Ф. (2002). Технологія продукції громадського харчування з використанням біологічно активних добавок [Монографія]. Київ: КНТЕУ.

Сімахіна, Г.О., \& Українець, А.І. (2010). Інноваційні технологї та продукти. Оздоровче харчування. Київ: НУХТ.

Снєжкін, Ю.Ф., \& Петрова, Ж.О. (2010). Харчові порошки з рослинної сировини. Класифікація, методи отримання, аналіз ринку. Biotechnologia Acta, 3(5), 31-42.

Тимченко, В.К., Зябченкова, А.К., \& Савус, А.А. (2007). Технология майонезов, салатних соусов и дрессингов. Харьков: НТУ «ХПИ».

Шендеров, Б.А. (2003). Современное состояние и перспективы развития концепции "Функциональное питание". Пищевая промышленность, 5, 4-7. 


\section{REFERENCES}

Halytska, L.Yu., \& Khyzhniak, O.O. (2014). Netradytsiina oliievmisna syrovyna v Ukraini [Non-traditional oil-containing raw materials in Ukraine]. In Tekhnichni nauky: stan, dosiahnennia i perspektyvy rozvytku m'iasnoi, oliiezhyrovoi ta molochnoi haluzei [Engineering Sciences: Status, Achievements and Prospects for Meat, Oil and Dairy Development] (pp. 144-146), Proceedings of the 3rd International Conference. Kyiv: NUKhT [in Ukrainian].

Dotsenko, V.F. (Ed.). (2016). Laboratornyi praktykum iz zahalnykh tekhnolohii kharchovoi promyslovosti [Laboratory Workshop on General Food Technology]. Kyiv: Kondor [in Ukrainian].

Ipatova, L.G., Kochetkova, A.A., \& Nechaev, A.P. (2006). Novye napravleniia zhirovykh produktov [New trends in fatty foods]. Maslozhirovaia promyshlennost, 4, 12-14 [in Russian].

Koretska, I.L., \& Zinchenko, T.V. (2003). Otsiniuvannia novykh kharchovykh vyrobiv za dopomohoiu kryteriiu "Bahatokutnyk yakosti" [Evaluation of new foods using the Quality Polygon criterion]. Naukovi pratsi NUKhT, 14, 64-65 [in Ukrainian].

Maionezy. Zahalni tekhnichni umovy [Mayonnaise. General specifications]. (2005). DSTU 4487:2005, 2005, 25 November. Kyiv: Ukrainskyi naukovo-doslidnyi instytut olii ta zhyriv (UkrNDIOZh) i asotsiatsiia "Ukroliiaprom" [in Ukrainian].

Maionezy. Pravyla pryimannia ta metody vyprobuvannia [Mayonnaise. Acceptance rules and test methods]. (2006). DSTU 4560:2006, 2008, 1 Januar. Kyiv: Ukrainskyi naukovo-doslidnyi instytut olii ta zhyriv (UkrNDIOZh) i asotsiatsiia "Ukroliiaprom" [in Ukrainian].

Morkva stolova sushena. Tekhnichni umovy [Dried carrots. Specifications]. (2016). DSTU 8654:2016, 2017, 1 July. Kyiv: DP "UkrNDNTs" [in Ukrainian].

Nechaev, A.P. (2007). Nauchnye osnovy tekhnologii polucheniia funktcionalnykh zhirovykh produktov novogo pokoleniia [The scientific basis of the technology for the production of functional fat products of a new generation]. Masla i zhiry, 8, 26-27 [in Russian].

Oseiko, M.I. (2006). Tekhnolohiia roslynnykh olii [Vegetable oil technology]. Kyiv: Varta [in Ukrainian].

Peresichnyi, M.I., \& Kravchenko, M.F. (2002). Tekhnolohiia produktsii hromadskoho kharchuvannia $z$ vykorystanniam biolohichno aktyvnykh dobavok [Food technology using biologically active additives] [Monograph]. Kyiv: KNTEU [in Ukrainian].

Simakhina, H.O., \& Ukrainets, A.I. (2010). Innovatsiini tekhnolohii ta produkty. Ozdorovche kharchuvannia [Innovative technologies and products. Wellness nutrition]. Kyiv: NUKhT [in Ukrainian].

Sniezhkin, Yu.F., \& Petrova, Zh.O.(2010). Kharchovi poroshky z roslynnoi syrovyny. Klasyfikatsiia, metody otrymannia, analiz rynku [Food powders from vegetable raw materials. Classification, methods of obtaining, market analysis]. Biotechnologia Acta, 3(5), 31-42 [in Ukrainian].

Timchenko, V.K., Ziabchenkova, A.K., \& Savus, A.A. (2007). Tekhnologiia maionezov, salatnikh sousov $i$ dressingov [Technology of mayonnaise, salad dressings and dressings]. Kharkov: NTU "KhPI" [in Russian].

Shenderov, B.A. (2003). Sovremennoe sostoianie i perspektivy razvitiia kontceptcii "Funktcionalnoe pitanie" [Current status and development prospects of the concept of "Functional Nutrition"]. Pishchevaia promyshlennost, 5, 4-7 [in Russian]. 


\title{
UDC 664.34
}

\section{Ihor Hryshchenko,}

Ph.D. in Technical Sciences, Associate professor, professor, Kyiv National University of Culture and Arts, Kyiv, Ukraine, grinnicol022@gmail.com https://orcid.org/0000-0001-9134-8456

\section{Nadiia Kravchuk,} Ph.D. in Technical Sciences, Associate Professor, National University of Food Technologies, Kyiv, Ukraine, kr.nadiya@gmail.com https://orcid.org/0000-0002-5405-6275

\author{
Olena Zborovska, \\ Assistant, \\ Kyiv National University of \\ Culture and Arts, \\ Kyiv, Ukraine, \\ alena-vlad2013@meta.ua \\ https://orcid.org/0000-0002-7297-8695
}

\section{INNOVATIVE TECHNOLOGIES OF MAYONNAISE SAUCE}

Actuality. The expediency of using blends of vegetable oils for correction of PUFA insufficiency and vegetable raw materials in the technology of mayonnaise sauce production is considered. The use of blended oil, balanced in fatty acid composition and carrot powder, combining the proposed ratios of all components provides original organoleptic characteristics of mayonnaise and at the same time gives it functional properties, increases nutritional and biological value.

Purpose and methods. The purpose of the article is to substantiate and develop betacarotene enriched mayonnaise technology. Research methods are organoleptic, physio-chemical, structural-mechanical, statistical.

Results. Technology of mayonnaise sauce is based on blending of corn-olive oil and carrot powder with balanced fatty acid composition.

Conclusions and Discussion. It has been established that the use of vegetable components, namely carrot powder and blended oils in mayonnaise technology, enables us to obtain high-value food. This will expand the range of sauces, enrich them with fat-soluble vitamins, antioxidants and PUFA class $\omega-6$ and $\omega-3$ in the optimal ratio.

Keyword: Mayonnaise, oil, carrot powder, sauce, polyunsaturated fatty acids (PUFA). 


\title{
УДК 664.34
}

\author{
Игорь Грищенко, \\ кандидат технических наук, \\ доцент, профессор, \\ Киевский национальный университет \\ культуры и искусств, \\ Киев, Украина, \\ grinnicol022@gmail.com \\ https://orcid.org/0000-0001-9134-8456 \\ Надежда Кравчук, \\ кандидат технических наук, доцент, \\ Национальный университет \\ пищевых технологий, \\ Киев, Украина, \\ kr.nadiya@gmail.com \\ https://orcid.org/0000-0002-5405-6275 \\ Елена Зборовская, \\ ассистент, \\ Киевский национальный университет \\ культуры и искусств, \\ Киев, Украина, \\ alena-vlad2013@meta.ua \\ https://orcid.org/0000-0002-7297-8695
}

\section{ИННОВАЦИОННЫЕ ТЕХНОЛОГИИ СОУСА МАЙОНЕЗ}

Актуальность. Рассмотрена целесообразность использования купажей растительных масел для коррекции недостаточности ПНЖК и растительного сырья в технологии производства соусов майонез. Использование купажированного масла, сбалансированнго по жирнокислотному составу и морковного порошка, сочетание предложенных соотношений всех компонентов обеспечивает оригинальные органолептические показатели майонеза и одновременно придает ему функциональных свойств, повышает пищевую и биологическую ценность. Цель и методы. Цель статьи - обосновать и разработать технологию соуса майонез, обогащенного бета-каротином. Методы исследования - органолептические, физико-химические, структурно-механические, статистические. Результаты. Разработана технология соуса майонеза на основе купажа кукурузно-оливкового масла и морковного порошка со сбалансированным жирнокислотным составом. Выводы и обсуждение. Установлено, что использование растительных компонентов, а именно морковного порошка и купажированных масел в технологии майонезов позволяет получить пищевой продукт повышенной пищевой ценности. Это позволит расширить ассортимент соусов, обогатить их жирорастворимыми витаминами, антиоксидантами и ПНЖК класса $\omega-6$ и $\omega-3$ в оптимальном соотношении.

Ключевые слова: майонез, масло, порошок из моркови, соус, полиненасыщенные жирные кислоты (ПНЖК). 